ДИСТАНЦІЙНЕ НАВЧАННЯ В МЕДИЧНОМУ ВУЗІ - РЕАЛІЇ СЬОГОДЕННЯ

\title{
DISTANCE LEARNING IN MEDICAL HIGHER EDUCATION INSTITUTIONS - REALITIES OF TODAY
}

УДК 378.147.157

DOI https://doi.org/10.32843/2663-

$6085 / 2021 / 31-1.32$

\section{Саган H.T.,}

канд. мед. наук,

асистент кафедри патофрізіології

Івано-Франківського національного

медичного університету

\section{Заяць Л.М.,}

\section{докт. мед. наук,}

завідувач кафедри патофрізіології

Івано-Франківського національного

медичного університету

\section{Жураківська О.Я.,}

докт. мед. наук,

профресор кафедри анатомії

Івано-Франківського національного

медичного університету

Антимис О.В.,

канд. мед. наук,

доцент кафедри анатомії

Івано-Франківського національного

медичного університету

\section{Дутчак У.М.,}

канд. мед. наук,

доцент кафедри анатомії

Івано-Франківського національного

медичного університету

Міськів В.А.,

канд. мед. наук,

доцент кафедри анатомії

Івано-Франківського національного

медичного університету
Сьогодні цілий світ став заручником пандемії COVID-19, яка вже забрала більше мільйона життів і заразила понад 30 мільйонів людей у 190 країнах. Вищі навчальні заклади зіткнулись із таким викликом, як організація дистанційного навчання в умовах карантинних заходів. Дистанційне навчання в сучасному розумінні - че інтегровані очне, вечірнє $і$ заочне навчання з використанням новітніх комп'ютерних технологій на основі використання всесвітніх і локальних комп'ютерних мереж (Internet). Основою дистанційного навчання (Distance Learning, Distance Education) є самостійна робота. Студент працює з викладачем дистанційно, відповідно до програми, за допомогою засобів телекомунікації. Самостійна робота - це форма організації навчального прочесу, коли студент індивідуально вивчає навчальний матеріал. Мета самостійноі роботи - допомагати студентові формувати особистісну самостійність як професійну якість, з умінням планувати, систематизувати, а також регулювати своє навчання без контролю викладача. Позитивними рисами дистанційного навчання у медичному виші є: можливість працювати зі значно більшою аудиторією; можливість ширше використовувати інтерактивні методи навчання; можливість займатися у зручній для себе обстановці; рівні можливості отримання освіти незалежно від стану здоров'я та матеріальної забезпеченості студента; стимулювання студентамедика до самоорганізації, самодисципліни, самостійного оволодіння матеріалом та самостійного прийняття відповідальних рішень, збільшуючи при цьому його інтелектуальний потенціал; стимулювання студента-медика вдосконалювати володінням комп'ютерною технікою; оновлення ролі викладача, який повинен підвищувати педагогічну активність і кваліфрікацію відповідно до інновацій та нововведень. Незважаючи на деякі негативні моменти, впровадження в медичному виші дистанційних технологій навчання себе виправдало $i$, можливо буде розвиватися як одна із форм освітнього прочесу в поєднанні з очним навчанням (змішаний навчальний процес). Ключові слова: дистанційне навчання, медичний ВНЗ, інноваційні технології.

Today, the whole world has become hostage to the Covid-19 pandemic, which has already claimed more than a million lives and infected more than 30 million people in 190 countries. Higher education institutions have faced the challenge of organizing distance learning in quarantine. Distance learning in the modern sense is an integrated full-time, part-time and distance learning using the latest computer technology based on the use of global and local computer networks (Internet). The basis of distance learning (Distance Learning, Distance Education) is independent work. The student works with the teacher remotely, according to the program by means of telecommunications. Independent work is a form of organization of the educational process in which the student individually studies the educational material. The purpose of independent work is to help the student to form personal independence as a professional quality, with the ability to plan, systematize and regulate their learning without the control of the teacher. The positive features of distance learning in medicalschool are: the ability to work with a much larger audience; opportunity to use interactive teaching methods more widely; opportunity to practice in a comfortable environment; equal opportunities for education - regardless of the state of health and financial security of the student; stimulating the medical student to self-organization, self-discipline, independent mastery of the material and independent decisionmaking, while increasing his intellectual potential; encouraging medical students to improve their computer skills; updating the role of the teacher, who should increase pedagogical activity and qualification in accordance with innovations and innovations. Despite some negative aspects, the introduction of distance learning technologies in medical schools has paid off and may develop as a form of educational process in combination with full-time education (mixed learning process).

Key words: distance learning, medical university, innovative technologies.
Постановка проблеми в загальному вигляді. Сьогодні цілий світ став заручником пандемії COVID-19. Минуло менше року після того, як ми вперше почули про пандемію, однак вона вже забрала більше мільйона життів і заразила більше 30 мільйонів людей у 190 країнах. Генеральний директор організації ЮНЕСКО заявила, що через цю пандемію, яка вимагає карантинних заходів, 1,5 мільярда молодих людей у 165 країнах світу не можуть відвідувати заняття [1, с. 131]. Тому виник запит на організацію дистанційного навчання.

Аналіз останніх досліджень і публікацій. В Україні цей вид навчання відомий як «заочний», на Заході - як «кореспондентський» (The Distance Education and Training Council - існує з 1926 року).
Деякі вчені вважають, що ідея навчання на відстані була ще в XVII столітті, коли Святий Павло відправляв усні посилання християнам [2, с. 119].

Розвиток технологій дистанційного навчання тісно пов'язаний з так званими «інфрормаційними революціями», тобто змінами інструментальної основи, способів передачі та збереження інформації. Вважається, що було 5 «інфрормаційних революцій» [3, с. 37]. Першою «інфрормаційною революцією» вважають розвиток мови як джерела спілкування. Другою - письменність та книгодрукування. Третя зробила інфрормацію публічною. Четверта «інфрормаційна революція» пов'язана із застосуванням електронної апаратури, що дало можливість швидкого поширення інфрормації. 
П'ятий етап характеризується створенням швидкісних комп'ютерів, наповненням автоматизованих баз даних, створенням і швидким розвитком комунікативних сіток.

Виділення не вирішених раніше частин загальної проблеми. Нині дистанційне навчання у медичних вишах тільки набирає свого розвитку і потребує нововведень і корекцій. Багато питань ще залишається поза увагою педагогів.

Формулювання цілей статті (постановка завдання). Мета нашого дослідження - проаналізувати методи дистанційного навчання та обґрунтувати доцільність його впровадження у педагогічний процес медичних вишів.

Виклад основного матеріалу дослідження. Дистанційне навчання в сучасному розумінні це інтегровані очне, вечірнє і заочне навчання 3 використанням новітніх комп'ютерних технологій на основі використання всесвітніх і локальних комп'ютерних мереж (Internet). Дистанційний спосіб навчання став доволі неочікуваним та випробовувальним для всіх учасників освітнього процесу. Однак у вищій школі за останні роки, відповідно до втілення в життя Болонської системи, почали широко використовуватись інтерактивні технології, які і стали рятівним колом під час упровадження дистанційного навчання [4, с. 117]. На кафредрі анатомії людини Івано-Франківського національного медичного університету (ІФНМУ) комп'ютерні технології за останній час широко впроваджені у навчальний процес. Навчальна програма передбачає перевірку знань за допомогою тестових завдань на кожному практичному занятті. Для цього на нашій кафедрі розроблені комп'ютерні контролюючі програми, які охоплюють матеріал із кожної теми, розділу, всього курсу дисципліни, що дає змогу об'єктивно оцінювати студента під час вивчення всього курсу. Звичайно, на кожному практичному занятті виділено час для тестування на початку (10 хв.) і в кінці (10 хв.) заняття. На початку заняття ми визначаємо початковий (вхідний) рівень знань студентів, тобто з якими знаннями вони прийшли на практичне заняття. Для цього ми використовуємо графрічні тести - це переважно тести з тестовими завданнями закритої форми на вибір однієї правильної відповіді. За їх допомогою перевіряють розуміння студентами суті основних положень практичного заняття. За результатами виконаного тесту відбувається умовний перерозподіл студентів на такі дві групи, як: студенти, які готові до сприйняття матеріалу, і студенти, які потребують додаткових індивідуальних консультацій викладача. Після закінчення цього тестування зазвичай проводиться «робота над помилками», впродовж якої студенти мають змогу проконсультуватися 3 викладачем стосовно допущених огріхів. Тести вхідного рівня знань $є$ своєрідним «сигналом» про початок заняття, дають можливість студентам налаштуватися на подальше сприйняття інорормації, а викладачу - зрозуміти слабкі сторони студентів для можливості в подальшому приділяти їм більше уваги, що дасть змогу значно покращити рівень знань академічної групи. Згідно з результатами тестування, повинна відбуватися корекція навчального процесу, але при цьому потрібно враховувати також можливості студента як у розумовому, так і у психологічному плані. У кінці кожного аудиторного заняття використовуються тести для визначення кінцевого рівня знань студентів, що складаються із ситуаційних завдань за темою заняття, взятих із бази тестів «Крок 1». Тести цього виду контролю передбачають перевірку, оцінку вміння обґрунтувати, проводити аналіз, шукати вирішення нестандартних завдань. У кінці кожного змістовного модуля навчальною програмою визначено складання підсумкового модульного контролю, основною частиною якого $€$ тестування. Для підсумкового тестування знову ж таки використовується база тестів «Крок 1» для студентів за темою цього змістовного модуля.

Основою дистанційного навчання (Distance Learning, Distance Education) $є$ самостійна робота [5, с. 31]. Студент працює 3 викладачем дистанційно, відповідно до програми за допомогою засобів телекомунікації. Самостійна робота - це фрорма організації навчального процесу, за якої студент індивідуально вивчає навчальний матеріал. Мета самостійної роботи - допомагати студентові формувати особистісну самостійність як профресійну якість з умінням планувати, систематизувати, а також регулювати своє навчання без контролю викладача. Слово «студент» (studens той, хто вчиться) означає необхідність наполегливої напруженої мозкової діяльності для оволодіння глибокими знаннями. Німецький педагог А. Дістервег визначив суть навчального процесу: «Розвиток і освіта ні одній людині не можуть бути дані або повідомлені. Усяк, хто бажає до них прилучитися, повинен досягнути цього власною діяльністю, власними силами, власним напруженням».

В Івано-Франківському національному медичному університеті самостійній роботі студентів відводиться пріорітетне місце. Самостійна робота студентів складається 3 кількох етапів: позааудиторна, аудиторна та творча робота. Студенти самостійно готуються до практичного заняття. На практичному занятті викладач ставить завдання студентам, які ті повинні самостійно вирішити. Для цього вони активно спілкуються між собою та отримують консультації викладача. Творча робота - це індивідуальна робота студентів, яка оцінюється під час вивчення кожного змістовного модуля, участі у конференціях та олімпіадах. Творча робота спрямована на розвиток у студента самостійності та ініціативи. 
У медичному виші дистанційне навчання є дещо невиправданим, оскільки основою медичної освіти $€$ професійне спрямування, що є важливим, враховуючи те, що від самосвідомості і компетентності студента-медика в подальшому буде залежати здоров'я, а можливо, і життя людини. Тому під час практичних занять широко використовують різноманітні муляжі, тренажери, віртуальні симулятори та інші технічні засоби навчання. Особливо важливим $є$ живе спілкування 3 профрільними хворими. Між лікарем і хворим мають встановитися міжособистісні стосунки, адже взаємодія між ними - це не простий обмін інформацією, а частина лікувального процесу. Якщо перефразувати висловлювання нашого відомого співвітчизника В.М. Бехтерєва, якщо хворий після зустрічі 3 лікарем не відчув полегшення, то був не лікар. Адже процес лікування передбачає поєднання як соматичних, так і психологічних впливів на хворого. Розмова 3 пацієнтом, уміння проникати у психологію пацієнта, навички відокремлювати головне від другорядного, диференціювати основні симптоми захворювання, виставляти діагноз та призначати еорективне лікування - це мистецтво, яке здобувається під час навчання у вищому медичному закладі. Для цього необхідною умовою є спілкування 3 досвідченими викладачами, які мотивують, спрямовують і координують навчальний процес та допомагають у спілкуванні з хворими. Спілкування з хворими є дещо утрудненим під час дистанційного навчання. Однак ми повинні вміти протистояти викликам часу. Пандемія коронавірусної інфрекції поставила перед нами завдання: зберегти систему медичної освіти, тим більше що невідомо, як у подальшому буде змінюватись епідеміологічна ситуація в Україні.

В Івано-Франківському національному медичному університеті для дистанційного навчання використовуються хмарні технології - інтернетплатформа Teams. До речі, широко використовуються і мобільні версії цих програм. У «хмарі» розміщені методичні матеріали кафедр, навчальні посібники, атласи, книги вітчизняних та зарубіжних авторів, презентації лекцій, тестові завдання, створені електронні журнали. Викладачі змушені були в короткий термін навчитися працювати 3 дистанційними платорормами. Позитивним моментом дистанційного навчання було те, що викладачі старшого покоління навчилися користуватися комп'ютером та інтернетом. Під час дистанційного навчання викладачі на кафедрі анатомії ІФНМУ розглядають тему заняття за допомогою презентацій та атласу зі схемами. Крім того, студенти проходять звичне тестування (визначення початкового і кінцевого рівня знань). Для складання підсумкового модульного контролю також використовувалися спеціальні презентації для теоретичної частини, презентації для практичних навичок (із препарованими частинами людського тіла) та ситуаційні завдання до цього розділу, вибрані 3 буклету ліцензійного іспиту «Крок 1».

За нашими спостереженнями, ще одним позитивним моментом дистанційного навчання є:

- можливість працювати зі значно більшою аудиторією;

- можливість ширше використовувати інтерактивні методи навчання;

- можливість займатися у зручній для себе обстановці;

- рівні можливості отримання освіти - незалежно від стану здоров'я та матеріальної забезпеченості студента;

- стимулювання студента-медика до самоорганізації, самодисципліни, самостійного оволодіння матеріалом та самостійного прийняття відповідальних рішень, збільшуючи при цьому його інтелектуальний потенціал;

- стимулювання студента-медика вдосконалювати володіння комп'ютерною технікою;

- оновлення ролі викладача, який повинен підвищувати педагогічну активність і кваліфікацію відповідно до інновацій та нововведень.

Однак ми на кафедрі анатомії людини зіткнулися 3 деякими труднощами, які полягають у тому, що до нас на навчання приходять першокурсники. Студенти, в минулому учні, відрізняються один від одного базовими знаннями, здібностями, характером, різною реакцією на зміну середовища. Крім того, навчання в університеті має свої особливості, такі як більший рівень вимог до знань, самостійна підготовка та самостійна робота. Тому майже всім першокурсникам потрібний перехідний період. А викладачам необхідно враховувати нюанси перехідного періоду та якомога більше допомагати в адаптації у виші.

Іншою негативною рисою дистанційного навчання ми вважаємо відсутність живого спілкування між викладачем і студентом. Це також не сприяє соціалізації студентів, оскільки вони не мають змоги спілкуватися один з одним.

Також дистанційне навчання називають «дорослим», тобто 3 високим рівнем освітньої самомотивації. Студенти повинні проявити себе досить свідомими, цілеспрямованими та наполегливими. І основною проблемою в Україні $€$ недоступність інтернету, особливо у невеликих містечках, а також шкідлива дія монітору.

Висновки. Незважаючи на незначні негативні моменти, ми думаємо, що дистанційне навчання у медичних вишах себе виправдало і, можливо, буде розвиватись як одна із фрорм освітнього процесу в поєднанні 3 очним навчанням (змішаний навчальний процес).

Століття назад американський педагог і фрілоcoф Джон Дьюї написав: «Якщо ми вчимо сьогоднішніх студентів так, як ми вчили вчорашніх, ми позбавляємо їх завтрашнього дня». Це і досі залишається актуальним. 
БІБЛІОГРАФІЧНИЙ СПИСОК:

1. Berezhna S., Prokopenko I. Higher Education Institutions in Ukraine during the Coronavirus, or COVID-19, Outbreak: New Challenges vs New Opportunities // Revista Romaneasca pentru Educatie Multidimensionala. 2020. Vol. 12, Is. 1 Sup. 2. P. 130-135.

2. Пьянников М.М. К вопросу об истории развития дистанционного обучения. Ученые записки Забайкальского государственного университета. Серия: Педагогические науки. 2011. С. 119-124.
3. Лукиных Т.Н., Можаева Г.В. Информационные революции и их роль в развитии общества. Гуманитарная инфрорматика. 2005. № 2. С.34-39.

4. Москаль Ю. Світові тенденції розвитку заочної та дистанційної вищої освіти. Психологія і суспільство. 2008. № 3. С. 116-122.

5. Васюк О. Теоретико-методичні аспекти організації дистанційної освіти. Вісник Книжкової палати України. 2011. № 2. С. 30-32. 